[Forthcoming The Law and Practice of International Courts and Tribunals 2020]

\title{
Procedural Developments in Investment Arbitration
}

\author{
By Szilárd Gáspár-Szilágyi and Maxim Usynin*
}

\section{Introduction}

In the world of investment arbitration 2019 and early 2020 have once again seen a rising number of cases brought by investors under various international investment agreements (IIAs) ${ }^{1}$, while in the world of policy UNCITRAL Working Group III is continuing its mandate to reform investor-State dispute settlement (ISDS). ${ }^{2}$ In this column, we will focus on procedural developments in recent investment arbitration cases, relying on publicly available interim decisions and final awards, handed down in the period of 1 January 2019 31 March 2020. Given the large number of new cases, decisions and awards, we decided to focus on a dozen of them, which we believe tackle novel issues or present complex procedural matters. The cases are grouped into several categories.

In the first group, we focus on the legal personality of the investor and discuss two secondary issues: the qualification of a ministry of a regional entity as an investor (Tatarstan v. Ukraine) and claims brought by dual nationals (Heemsen v. Venezuela and Garcia Armas v. Venezuela). Even though these issues concern jurisdictional matters ratione personae, they shall be discussed separately from other jurisdictional matters.

The second group discusses other jurisdictional matters. In one case, a dissenting arbitrator argued that the tribunal should decline jurisdiction under an intra-EU BIT (Adamakopoulos v. Cyprus). In another, the Tribunal imported an umbrella clause from another treaty via the bilateral investment treaty's (BIT) MFN clause (Consutel v. Algeria). In a more unusual case, the Tribunal found insufficient evidence that the underlying BIT had entered into force despite its ratification by the national parliaments (Besserglik $v$. Mozambique).

\footnotetext{
*Szilárd is a Lecturer at Keele University School of Law (s.gaspar-szilagyi@ keele.ac.uk). Maxim is a Research assistant at CEPRI - Centre for Private Governance, University of Copenhagen (maksim.usynin @ jur.ku.dk). This column includes the authors' own academic opinions, which may change with time.

1 See 'World Investment Report 2019' (UNCTAD) <https://unctad.org/en/PublicationsLibrary/ wir2019_en.pdf> accessed 5 April 2020. The Report includes 71 new arbitrations in 2018.

2 'Investor-State Dispute Settlement Reform' (UNCITRAL Working Group III) <https://uncitral.un.org/ en/working_groups/3/investor-state> accessed 5 April 2020.
} 
The third group concerns interim decisions and provisional orders. In one case the Tribunal discussed the intimidation of witnesses (Manolium v. Belarus) while in Grace v. Mexico the Tribunal ordered the disclosure of ongoing criminal proceedings against the investors' counsel.

In the fourth group we turn our attention to conditional or alternative remedies, discussing the case of Hydro Energy 1 v. Spain, contrasting it to the 2016 award in Arif v. Moldova. This is followed by the final group discussing domestic enforcement proceedings in the post-Achmea world: Eiser v. Spain (Federal Court of Australia) and PL Holdings v. Poland (Supreme Court of Sweden).

\section{Who qualifies as an investor?}

The question of who qualifies as an investor in an investment arbitration dispute is a question of jurisdiction rationae personae. Thus, in the absence of a covered foreign investor, the tribunal must decline jurisdiction. This section looks at two recent developments. First, in the yet to be published decision in Tatarstan $v$. Ukraine, ${ }^{3}$ the Tribunal discussed whether a ministry of a Russian federal subject qualified as an investor. Second, in two cases brought against Venezuela, the tribunals declined jurisdiction due to the dual nationality of the investors.

\subsection{A Federal Subject and its Ministry as an 'Investor'}

The decision on jurisdiction in Tatarstan $v$. Ukraine remains unpublished so we do not yet have access to the detailed reasoning of the Tribunal. Nevertheless, various secondary sources ${ }^{4}$ provide a basic overview of the case, raising some interesting questions.

Two arbitrations arose out of the same dispute concerning various judicial measures of Ukrainian courts against the oil refinery 'Ukrtatnafta' in 2007. The first case of Tatneft $v$. Ukraine $^{5}$ was successfully brought by a Russian energy company under the Russia-Ukraine BIT (1998). The Claimant's largest shareholder was a Russian federal subject, the Republic of Tatarstan. Unlike the first case, the second case was not brought by a company, but directly

\footnotetext{
${ }^{3}$ Ministry of Land and Property of the Republic of Tatarstan v. Ukraine, UNCITRAL Ad hoc, Award on Jurisdiction (9 December 2019). Arbitrators: Lucy Reed (P), Karl Heinz Böckstiegel, and Philippe Sands.

${ }^{4}$ Investment Arbitration Reporter (IA Reporter) $<$ https://www.iareporter.com/> accessed 5 April 2020; 'Cases - Advanced Search' (International Centre for Settlement of Investment Disputes) $<$ https://icsid.worldbank.org/en/Pages/cases/AdvancedSearch.aspx > accessed 5 April 2020; 'CIS Arbitration Forum' $<$ http://www.cisarbitration.com/> accessed 5 April 2020.

${ }^{5}$ OAO Tatneft v. Ukraine, PCA Case No. 2008-8.
} 
by a State organ. The case was launched in 2016 by Tatarstan and the Tatarstan Ministry of Land and Property Relations ('the Ministry), as the Republic of Tatarstan held shares in Ukrtatnafta.

According to IA Reporter the UNCITRAL tribunal "held that the Republic of Tatarstan did not qualify as an "investor" under the BIT, but it did recognize such standing to the [Ministry]." $"$ The case will proceed to the merits in respect of the claim brought by the Ministry while "on January 7, 2020, Ukraine initiated set-aside proceedings against the jurisdictional award before the Paris Court of Appeal."7

The decision raises two important questions. First, should investor-State arbitration only protect private investors or also State's or organs of a State investing in another country? Second, for the purposes of international law, when can a State be separated from its constituent elements?

Regarding the first question, the original purpose of the ICSID Convention and investor-State arbitration (ISA) was to "encourage" and protect private investments and private investors. ${ }^{8}$ This purpose is also evident in the Preamble ${ }^{9}$ and Article 1(2) of the ICSID Convention, the latter expressly stating that the purpose of the Convention is to provide dispute settlement facilities for Contracting States and "nationals of other Contracting States". The Tatarstan decision, however, seems to go against the overall spirit and raison d'être of ISA, BITs and investment law to protect the investments of private entities and not public ones or private entities "whose links with the State are so tight that they cannot be considered as distinct entities". 10

Even if the decision is yet to be public, one can identify potential paths available to the Tribunal in coming to its conclusion. One could argue that the outcome was influenced by the underlying arbitration rules. Unlike the ICSID Convention, the UNICTRAL Arbitration Rules refer generally to "parties" to a dispute, without specifying whether they are public or private. Furthermore, the definition of 'investor' under the Russia-Ukraine BIT allows an expansive interpretation that includes state organs, as public bodies, and not just private investors. Article 2(b) of the Russia-Ukraine BIT defines "investor of a Contracting Party"

\footnotetext{
${ }^{6}$ Vladislav Djanic, "BIT Claim Against Ukraine is Allowed to Proceed, but One of the Claimants - The Republic of Tatarstan - Fails to Clear Jurisdictional Hurdle", Investment Arbitration Reporter (18 February 2020) <https://www.iareporter.com/articles/claim-against-ukraine-is-allowed-to-proceed-but-one-of-theclaimants-fails-to-clear-jurisdictional-hurdle/> accessed 5 April 2020.

${ }^{7}$ Ibid.

${ }^{8}$ ICSID, "History of the ICSID Convention", Volume I, p. 2. See also T. St. John, The Rise of Investor-State Arbitration (2018).

${ }^{9}$ The Preamble mentions "private international investment" and "nationals of other Contracting States".

${ }^{10}$ Giulio Alvaro Cortesi, "ICSID Jurisdiction with Regard to State-Owned Enterprises - Moving Toward an Approach Based on General International Law", 16 The Law and Practice of International Courts and Tribunals (2017) 108, 112 with reference to the "Broches test".
} 
to include besides natural persons, "any legal entity, set up or instituted in conformity with the legislation prevailing on the territory of the given Contracting Party, under the condition that the said legal entity is legally capable, under the legislation of its respective Contracting Party, to carry out investments on the territory of the other Contracting Party" [emphasis added]. Thus, if a ministry of Tatarstan, as a public legal entity, can carry out investments abroad under Russian law, then it should qualify as a foreign investor in the Ukraine. Contrast this to the more restrictive definition in Article 8.1 of CETA, which includes natural persons and 'enterprises' of the other contracting party; thus, private legal entities not public ones.

Second, the Tatarstan decision contributes to the discussion on when a State can be separated from its constituent elements for the purposes of international law. ${ }^{11}$ States are responsible for the conduct of their 'organs' as well as other entities exercising government authority. ${ }^{12}$ Thus, if the Russian Federation were the Respondent, it could be held responsible for the actions or inactions of any of the federal and sub-federal level 'organs' as well as other persons and entities exercising government authority. Whether the State can be held responsible for the conduct of state-owned enterprises is a more fact-specific question, as illustrated in the recent Staur Eiendom v. Latvia case in which an ICSID tribunal held that Latvia was not responsible under Articles 4 and 5 ARSIWA for the actions of a State owned airport. ${ }^{13}$ Nonetheless, for the purposes of being qualified as an 'investor' under a BIT, it seems that the State can be detached from its various 'organs', be they at the federal or subfederal levels.

The Tatarstan v. Ukraine case further complicates matters. The Republic of Tatarstan as such is a federal subject of the Russian Federation and the Tribunal held that it did not qualify as an investor. However, an organ of the federal subject (the Ministry) did qualify as such. A brief inquiry into Russian law suggests that the Ministry participates in civil law relations as a government institution, which has certain limitations concerning its civil law rights and liabilities. ${ }^{14}$ The Republic of Tatarstan would have a property title over its assets, while the institution will hold them on a limited title of operational management. ${ }^{15}$ In other words, the Republic remains the owner of the Ministry's assets, which only adds to the perception of the 'façade' of its corporate form.

\footnotetext{
${ }^{11}$ See also The Region of Kaliningrad v. Lithuania, ICC.

${ }^{12}$ Articles on Responsibility of States for Internationally Wrongful Acts (International Law Commission 2001) [ARSIWA], Articles 4-5. See also Article 8 for persons and groups of persons.

${ }^{13}$ Staur Eiendom AS, EBO Invest AS \& Rox Holding AS v. Republic of Latvia, ICSID Case No. ARB/16/38, Award (28 February 2020), paras. 329-354. Arbitrators: Eric Schwartz (P), Kaj Hobér, and Toby Landau.

${ }^{14}$ Russian Budget Code, Section 161(11); Russian Civil Code, Section 123.22.

${ }^{15}$ Russian Civil Code, Section 123.21(1); Resolution of the Cabinet of Ministers of the Republic of Tatarstan dated August 22, 2007 No. 407 "Issues of the Ministry of Land and Property Relations of the Republic of Tatarstan", Section 1.1.
} 
In conclusion, the Tatarstan decision seems to go against the overall spirit and purpose of ISA to protect the investments of private entities and not public ones. Furthermore, it is unclear whether one can somewhat artificially separate the federal or sub-federal subjects from their constituent organs for the purposes of qualifying the latter as an investor but not the former. Is a ministry not part of the State? On the other hand, for the purposes of the international responsibility of the State such separation is not allowed.

\subsection{Dual Nationals}

The Tribunals - in the two cases discussed in this section - denied jurisdiction ratione personae due to the dual nationality of the claimants, albeit using slightly different arguments. As both cases were rendered in Spanish, we used our own translation.

In Heemsen $v$. Venezuela, ${ }^{16}$ the Claimants relied on the Germany-Venezuela BIT (1996), alleging that a series of Venezuelan measures, such as the forced acquisition of a piece of their property, amounted to indirect expropriation. The Respondent, among others, argued that the Tribunal had no jurisdiction to hear the claims. In its Decision on Jurisdiction, the Tribunal upheld the Respondent's objection and ordered the Claimants to reimburse its legal costs.

The arguments of the Parties focused on the German nationality of the Claimants, the applicability of the BIT to dual nationals, and the applicability of the principle of effective and dominant nationality. The Tribunal first held that the Respondent did not manage to prove that the Claimants did not have the German nationality when making the investment. Nevertheless, the dual nationality of the Claimants seriously affected the Tribunal's jurisdiction ratione personae. ${ }^{17}$ The Tribunal then presented its arguments for denying jurisdiction.

First, the Tribunal argued that in the BIT the contracting parties designated ICSID as the main forum for settling investment disputes. This evidenced the contracting parties' clear intention not to offer protection to dual citizens. ${ }^{18}$ It is somewhat strange that the Tribunal chose to open its arguments with a reference to ICSID, given that the claim was filed under the UNCITRAL Arbitration Rules and administered by the PCA.

Second, the Tribunal admitted that Article 1(3) of the BIT did not expressly exclude dual citizens. Nevertheless, the contextual interpretation of the provision required looking at

\footnotetext{
${ }^{16}$ Enrique Heemsen and Jorge Heemsen v. Bolivarian Republic of Venezuela, PCA Case No. 2017-18, Decision on Jurisdiction (29 October 2019). Arbitrators: Yves Derains (P); Brigitte Stern, and Enrique Gómez-Pinzón.

${ }^{17}$ Ibid., para. 412.

${ }^{18}$ Ibid., para. 413.
} 
the whole text of the BIT. ${ }^{19}$ The Tribunal then referred to the preamble of the BIT which refers to investments from one contracting party into the other contracting party. ${ }^{20}$ Furthermore, the dispute resolution clause in Article 10(2) BIT not only contained a similar reference, but also allowed bringing claims under the ICSID Convention, which notoriously does not allow dual nationals to initiate ISA. ${ }^{21}$ Consequently, the covered 'investor' under Article 1 BIT had to hold the nationality of either Germany or Venezuela, but could not be a national of both. ${ }^{22}$

Third, the Tribunal did not agree with the Claimant's argument that public international law provides general protection for dual citizens. ${ }^{23}$ Among others, the Tribunal referred to the 1930 Hague Convention on Conflict of Nationality Laws which in Article 4 states that "A State may not afford diplomatic protection to one of its nationals against a State whose nationality such person also possesses." 24 The Tribunal further argued that only those dual nationals could bring a claim against a State, who were more "foreign than national", referring to their dominant and effective nationality. ${ }^{25}$ Using the ICJ's criteria in the Nottebohm case, ${ }^{26}$ the Tribunal concluded that for the purposes of the dispute the investors were nationals of the Respondent; they were born in Venezuela, they were domiciled there, they incorporated companies in the country as Venezuelans, and they did not register locally as foreign investors.

In conclusion, the Tribunal closed both avenues for dual nationals to use the BIT. On the one hand, the Tribunal interpreted the BIT, using its preamble and its provisions referencing the ICSID Convention, so as not to offer protection to dual nationals. On the other hand, even if dual nationals could bring a case, they could not do so against their State of dominant and effective nationality.

The second case of Garcia Armas v. Venezuela ${ }^{27}$ was also administered by the PCA under the UNCITRAL Arbitration Rules. The Claimants brought the proceedings under the Spain-Venezuela BIT (1995) alleging the violation of the protection against expropriation without compensation under the BIT and other provisions of international law. ${ }^{28}$ The

\footnotetext{
${ }^{19}$ Ibid., para. 414.

${ }^{20}$ Ibid., para. 415.

${ }^{21}$ See Art 25(2) ICSID Convention, which contains an absolute prohibition for dual nationals to bring a case.

${ }^{22}$ Heemsen $v$ Venezuela (n 16), para. 417.

${ }^{23}$ Ibid., para. 420.

${ }^{24}$ Ibid., para. 423.

${ }^{25}$ Ibid., para. 433.

${ }^{26}$ Ibid., para. 441.

27 Manuel García Armas et al. v. Bolivarian Republic of Venezuela, PCA Case No. 2016-08, Award on Jurisdiction (13 December 2019). Arbitrators: José Emilio Nunes Pinto (P), Enrique Gómez-Pinzón, and Santiago Torres Bernárdez.

${ }^{28}$ Ibid., para. 3.
} 
Respondent's main defence was that the BIT did not apply to dual citizens. Additionally, it also submitted that the BIT only protected the investments of dual nationals in the country where they did not have the dominant nationality. The Claimants, on the other hand, argued that the BIT applies to dual nationals and there are no limitations on bringing claims. ${ }^{29}$

The Tribunal, just as the Heemsen Tribunal, also declined jurisdiction, but devoted a larger section of its decision to the issue of dual nationality. It first clarified that the case concerned dual citizens, who were natural persons and one of their nationalities was that of the Respondent, such as in Champion Trading v. Egypt, Serafín García Armas v. Venezuela and Rawat v. Mauritius. ${ }^{30}$

The Tribunal began its analysis by referring to the prohibition of diplomatic protection for dual nationals, enshrined in Article 4 of the Hague Convention mentioned above. The Tribunal further found support for the principle in various arbitration cases of the $19^{\text {th }}$ and early $20^{\text {th }}$ centuries, as well as the UN Reparations Advisory Opinion of the ICJ. ${ }^{31}$ The Tribunal also referred to Article 25(2)(a) ICSID Convention (supra). Notably, during the negotiations of the ICSID Convention, both Venezuela and Spain formed part of the group of States that militated for the absolute prohibition for dual nationals to launch claims. ${ }^{32}$

The second part of the Tribunal's analysis focused on the "dominant" nationality argument. In support, it mentioned the older arbitrations of de Brissot and Mathison, the ICJ's Nottebohm case, the 1955 Mergé case of the Italo-American Conciliation Commission and case $A / 18$ of 1984 of the US-Iran Claims Tribunal, all discussing the dominant nationality of claimants. ${ }^{33}$ Furthermore, the Tribunal referred to the NAFTA arbitration in Feldman v. Mexico in which the US argued that if a treaty is silent on double nationals, then the rules of public international law should be used. According to the Feldman Tribunal, the existence of dual citizenship presupposes the application of the dominant nationality rule. ${ }^{34}$

The Tribunal then questioned whether investment law contained lex specialis rules in relation to whether double nationals can bring a case. ${ }^{35}$ To the contrary, the Tribunal concluded that investment law doctrine favoured the application of the rules of general international law to investment law. ${ }^{36}$ Furthermore, allowing dual nationals to bring claims

\footnotetext{
${ }^{29}$ Ibid., para. 659.

${ }^{30}$ Ibid., para. 649.

31 Ibid., paras. 650-51, 664.

${ }^{32}$ Ibid., paras. 666-67.

${ }^{33}$ Ibid., paras. 675-682.

34 Ibid., para. 690 referencing Marvin Roy Feldman Karpa v. United Mexican States, ICSID Case No. ARB(AF)/99/1, Interim Decision on Preliminary Jurisdictional Issues (6 Dec 2000), para. 31.

${ }^{35}$ Ibid., para. 692.

${ }^{36}$ Ibid., paras. 693-95.
} 
would create uncertainty for the Respondent States since their own nationals could bring cases against them, after having obtained another nationality. ${ }^{37}$

The Tribunal also rebuffed some of the arguments of the Claimants based on the ICJ's Barcelona Traction $^{38}$ and Diallo ${ }^{39}$ cases. First, Barcelona Traction was not applicable to the present case as it concerned corporate nationality and not the nationality of natural persons. ${ }^{40}$ Second, even though the ICJ in Diallo stated that nationality in investment cases is "essentially" governed by BITs, the Tribunal held that this is not "completely" so. Investment law is not "divorced" from general international law, which the Tribunal had to apply pursuant to Article XI(4)b BIT. ${ }^{41}$

Following this exposé of the relevant rules of international law, the Tribunal looked at whether the BIT allowed for dual nationals to bring a case against their country of nationality. ${ }^{42}$ Similarly to the Heemsen case, the BIT did not expressly exclude dual nationals. Yet, its preamble formed part of the context for interpretation and spoke of investors from one contracting party bringing a case against the other contracting party. ${ }^{43}$

The Tribunal also drew a line between the Serafin Garcia Armas v. Venezuela case and the case at hand. In the former the Respondent voluntarily accepted the application of the UNCITRAL Rules, while in the latter the Respondent objected to them, claiming the availability of ICSID rules under the BIT. Furthermore, the Tribunal did not agree with the Serafin Tribunal's conclusion that rules of customary international law do not apply to investment law. ${ }^{44}$ In the end, the Tribunal considered the Claimants to be Venezuelan nationals, pursuant to the dominant nationality principle, while their Spanish nationality was only formal. ${ }^{45}$

Whilst the arguments used by the Heemden and Garcia Armas Tribunals are not identical, they share some similarities. First, both tribunals acknowledged that investment law is not separate from public international law. For this reason, they amply used sources of general international law, such as the prohibition of dual nationals to claim diplomatic protection against their state of nationality (Art. 4 of the 1930 Hague Convention) or the rules on the nationality of natural persons (Nottebohm). Consequently, the issue of dual nationality

${ }^{37}$ Ibid., para. 697.

38 Barcelona Traction, Light and Power Company, Limited (Belgium v. Spain), International Court of Justice, Judgment (5 February 1970).

${ }^{39}$ Ahmadou Sadio Diallo (Republic of Guinea v. Democratic Republic of the Congo), International Court of Justice, Judgment (24 May 2007).

${ }^{40}$ Armas v. Venezuela (n 27), para. 699.

${ }^{41}$ Ibid., para. 704.

${ }^{42}$ Ibid., para. 705.

${ }^{43}$ Ibid., para. 709.

${ }^{44}$ Ibid., para. 726.

45 Ibid., para. 734. 
in ISA must be seen in light of the general principles of international law. This means that even if the BIT is silent on the issue of dual nationality, the tribunals can use the VCLT rules on treaty interpretation to interpret the term 'investor' in light of the overall context of the BIT, which includes the preamble and other articles. Furthermore, they can use Article 4 of the Hague Convention to argue that an investor should not be able to bring a claim against a country of which it is a national. Moreover, even if exceptions to this principle exist, in both cases the claimants had the 'effective and dominant' nationality of the respondent State. This means that there might be instances in which some tribunals would be willing to allow a case brought by a dual national if the 'effective and dominant' nationality is that of the Home State and not the Host State. Third, both Tribunals - as a means of solidifying their conclusions - also highlighted that the BITs in question referred to the ICSID Convention, which expressly prohibits cases brought by dual nationals. Such references to the ICSID Convention form part of the overall context in which the term 'investor' must be interpreted. This approach is similar to that used by tribunals in previous cases, such as in Rawat $v$. Mauritius, in which the Tribunal held that a reference in Article 9 France-Mauritius BIT to ICSID was part of the context for interpreting the term investor as not applying to dual nationals. $^{46}$

In conclusion, dual nationals will find it difficult to bring a case against a State the nationality of which they possess, especially if the BIT references the ICSID Convention. There remains a possibility that some tribunals could allow a case brought by dual nationals, if the BIT does not reference ICSID and the 'effective and dominant' nationality is that of the Home State and not the Host State.

\section{Declining Jurisdiction}

\subsection{The first dissenting opinion declining jurisdiction in an intra-EU BIT case.}

For the past fifteen years, ${ }^{47}$ tribunals have been discussing the relationship between EU law and BITs concluded between EU Member States (intra-EU BITs). Then, in 2018 the CJEU delivered its Achmea ruling, holding that Articles 267 and 344 TFEU preclude ISDS provisions in intra-EU BITs, such as the ones under the Slovakia-Netherlands BIT. ${ }^{48}$ One

\footnotetext{
${ }^{46}$ Dawood Rawat v. The Republic of Mauritius, PCA Case 2016-20, Award on Jurisdiction (6 April 2018), paras. 178-179. Arbitrators: Lucy Reed (P), Jean-Christophe Honlet, and Vaughan Lowe.

47 The first such case that we know of is Eastern Sugar v. Czech Republic, SCC 088/2004, Partial Award (27 March 2007). Arbitrators: Pierre Karrer (P), Robert Volterra, and Emmanuel Gaillard.

48 Slovak Republic v. Achmea BV, Court of Justice of the European Union, Case C-284/16, ECLI:EU:C:2018:158, Judgment (6 March 2018).
} 
could have expected that this ruling would have prompted intra-EU arbitral tribunals to decline their jurisdiction. The opposite has happened. As we have argued elsewhere, ${ }^{49}$ so far, every intra-EU tribunal has upheld their jurisdiction using various legal arguments, some arguments by now becoming recurring motifs in several awards and decisions. The majority of the Tribunal in the intra-EU ICSID case of Adamakopoulos v. Cyprus ${ }^{50}$ proceeded in the exact same manner and upheld their jurisdiction, despite the objections of Cyprus and the EU Commission. However, to our knowledge, for the first time one arbitrator (Professor Marcelo Kohen) did not agree with the majority's conclusion, offering compelling reasons for application of EU law to the dispute.

In this case 951 Greek nationals and one Luxembourgish company brought a claim against Cyprus under the Greece-Cyprus BIT (1992) and the Belgium-Luxembourg-Cyprus BIT (BLEU-Cyprus 1991). They argued that the 2012-2013 fiscal and financial measures adopted by Cyprus following their bailout after the last economic crisis amounted to an expropriation of their assets. It is somewhat not surprising that the dissent came from the arbitrator appointed by the party that has arguably faced a negative outcome by the majority's decision. ${ }^{51}$ Nonetheless, the dissent shows a sound knowledge of both public international law and EU law, and it is worth discussing.

The dissenting arbitrator first looked at whether the treaty parties had tacitly terminated the intra-EU BITs pursuant to Article 59 VCLT. ${ }^{52}$ He concluded that Article 59 cannot form the basis of implicit termination due to the inconsistent approach of the contracting parties concerning the termination of the BITs. ${ }^{53}$ Thus, he concluded that the BITs were still in force under international law.

Professor Kohen then looked at whether Article 30 VCLT, on the application of successive treaties relating to the same subject matter, could apply. If the EU Treaties and the BITs related to the same subject matter, then the BITs could be incompatible with the EU Treaties. ${ }^{54}$ He then turned his attention to Article 351 TFEU on the relationship between prior

\footnotetext{
${ }^{49}$ See Szilárd Gáspár-Szilágyi and Maxim Usynin, "The Uneasy Relationship between intra-EU Investment Tribunals and the Court of Justice's Achmea Judgment", 4 European Investment and Arbitration Law Review (2019), 29.

${ }^{50}$ Theodoros Adamakopoulos and others v. Republic of Cyprus, ICSID Case No. ARB/15/49, Decision on Jurisdiction (7 February 2020). Arbitrators: Donald M. McRae (P), Alejandro Escobar, and Marcelo G. Kohen.

${ }^{51}$ See Szilárd Gáspár-Szilágyi and Laura Létourneau-Tremblay, "Who Are the Dissenting Arbitrators in International Investment Treaty Arbitration?", in Freya Baetens (ed.), Identity and Diversity on the International Bench (OUP, forthcoming 2020); Albert Jan van den Berg, "Dissenting Opinions by PartyAppointed Arbitrators", in Mahnoush Arsanjanu et al. (eds), Investment Arbitration in Looking at the Future: Essays on International Law in Honor of W. Michael Reisman (Brill Academic 2011) 842.

${ }^{52}$ Adamakopoulo v. Cyprus (n 49), para. 7.

${ }^{53}$ Ibid., para. 10.

${ }^{54}$ Ibid., para. 12.
} 
agreements of EU Member States and the EU Treaties. After concluding that this provision applies to the situation of intra-EU BITs, as they were concluded prior to Cyprus' accession to the EU, he held that Article 351 TFEU was relevant because it "is the explicit provision of the later treaty dealing with conflict of rules with prior treaties". 55

Professor Kohen's analysis then focused on demonstrating that intra-EU BITs and EU Law were in fact dealing with the same subject matter when it came to the treatment of investments. ${ }^{56}$ Using various EU legal sources, he argued that the free movement of capital offers broader coverage than the term 'investment' under BITs. On top of this, EU law recognized the principles of non-discrimination, legitimate expectations, the right to property, the free transfer of capital, etc. ${ }^{57}$ Thus, "EU investors enjoy within the EU more substantial rights and privileges than non-EU investors, even with regard to those non-EU investors having the benefit of the protection of BITs." 58 Concerning the provisions on dispute settlement, the dissenting arbitrator also argued that EU law provides not only for domestic courts, but also for adjudication before an international tribunal, the CJEU. ${ }^{59}$

He also showed a deep understanding of the CJEU's case law (referring to Achmea, Mox Plant, and Opinion 2/13) on the incompatibility of certain international agreements and their dispute settlement mechanisms with EU Law. ${ }^{60}$ He even went further to analyse whether intra-EU BITs would go against the principle of non-discrimination under Article 18 TFEU, which the CJEU did not answer in Achmea. ${ }^{61}$ Upon the extensive analysis of EU Law and the VCLT, Professor Kohen concluded that several articles of the intra-EU BITs, including the ones on dispute settlement, became inapplicable. He also criticized the majority arbitrators for disregarding the authentic interpretation of the contracting parties on the fate of intra-EU BITs. The statements were made at least two times, in the January 2019 Declaration of EU Member States and in the Joint Information Note of Cyprus and Greece. According to them, following Achmea, intra-EU BITs are not only incompatible with EU law, but they are also inapplicable. ${ }^{62}$ As a result, EU law takes precedence over intra-EU BITs and ISDS clauses contained in them are inapplicable.

Albeit a dissent, the approach of Professor Kohen is commendable. If it were followed by the majority, it would have provided much needed certainty and clarity in intra-EU cases (including the enforceability of arbitral awards), until all the intra-EU BITs and their sunset

\footnotetext{
${ }^{55}$ Ibid., para. 21.

${ }^{56}$ Ibid., para. 24.

${ }^{57} \mathrm{Ibid}$., para. 25.

${ }^{58} \mathrm{Ibid}$., para. 27.

${ }^{59}$ Ibid., para. 34.

${ }^{60}$ Ibid., para. 43.

${ }^{61}$ Ibid., para. 46.

${ }^{62} \mathrm{Ibid}$., para. 52.
} 
clauses are terminated. The dissenting arbitrator focused both on the importance of Article 30 VCLT and the importance of considering the EU Treaties not only as subsequent agreements to the two intra-EU BITs, but also as providing for a very deep and far reaching relationship between the EU Member States. Unlike other tribunals, Professor Kohen found that the two sets of treaties are incompatible with each other as there is substantive overlap between them. For this he relied on the ILC Study Group's observations that "[t]he test of whether two treaties deal with the "same subject matter" is resolved through the assessment of whether the fulfilment of the obligation under one treaty affects the fulfilment of the obligation of another". ${ }^{63}$ Furthermore, he realized the importance of Article 351 TFEU as a conflict rule between the EU Treaties and prior international agreements of the Member States. Lastly, he acknowledged that the CJEU's stance on the compatibility of other dispute settlement mechanisms with EU law is not something that first occurred in Achmea, but it is a part of a long line of cases that even predate most intra-EU BITs.

\subsection{Contractual Claims, State Owned Enterprises, and Importing an Umbrella Clause via the MFN Clause}

In the recent PCA case of $\underline{\text { Consutel } v . ~ A l g e r i a ~}^{64}$ - decided under the UNCITRAL Arbitration Rules - the Italian claimant argued that the Tribunal had jurisdiction under the Algeria-Italy BIT (signed in 1991, terminated in 2013). The award was rendered in French and we used our own translation.

The case concerned a partnership agreement ('the contract') between Algérie Télécom ('AT'), an Algerian state-owned telecommunications company, and the local subsidiary of a Canadian company, the majority of which was later acquired by the Italian investor. The contract concerned the development of a fibreoptic network, but it ran into difficulties and it was later abandoned. The Claimant argued that AT's breach of the contract was attributable to the State and violated the prohibition of expropriation, the FET standard, and the umbrella clause under Article 10(1) BIT.

The Tribunal commenced the assessment by admitting the non-binding character of prior arbitral decisions, which nevertheless contribute to the harmonious development of IIL. ${ }^{65}$ After having concluded that the Claimant was an investor under the BIT and had made an investment, the Tribunal turned to the question of whether the acts and omissions of AT

\footnotetext{
${ }^{63}$ Ibid., para. 23.

${ }^{64}$ Consutel Group S.p.A. in liquidazione v. People's Democratic Republic of Algeria, PCA No. 2017-33, Final Award (3 February 2020). Arbitrators: Alexis Mourre (P), Attila Tanzi, and Ahmed Mahiou.

${ }^{65}$ Ibid., para. 290.
} 
amounted to a breach of the BIT. ${ }^{66}$ The question of whether the conduct of AT was attributable to the Respondent State was relegated to the merits part. ${ }^{67}$ For the purposes of the jurisdictional assessment the Tribunal presumed that it was. This was followed by a tripartite argumentation.

First, the Tribunal held that the violations of the contract cannot themselves constitute the basis of the Tribunal's jurisdiction pursuant to the BIT unless the sovereign, public powers of the State were engaged. ${ }^{68}$ The Tribunal substantiated its arguments by referring to the holdings of prior arbitral tribunals, such as in Waste Management II, Azurix v. Argentina and Salini v. Jordan. According to the Tribunal the Claimant did not prove that AT's breach of its contractual obligations involved in any way the exercise of sovereign powers. ${ }^{69}$ Furthermore, the author of the act does not matter as much as the nature of the act and whether ius imperium was involved. ${ }^{70}$ The Tribunal concluded that the suspension of the contract was based on force majeure and not on a sovereign act of the State.

Second, the Tribunal addressed the Claimant's argument that Article 10(1) BIT was in fact an umbrella clause. ${ }^{71}$ Using the customary rules of treaty interpretation, the Tribunal concluded that the provision applied to the State's commitments concerning investments. Its purpose is to guarantee compliance with commitments specifically made regarding the investment, which did not cover other contractual obligations of the State. Thus, the compliance clause could not elevate the contractual commitments to the level of a treaty violation. The Tribunal referred to Arif v. Moldova, in order to delineate between Article 10(1) BIT (characterized in the investment law doctrine as a preservation of rights clause, as explained below) and an umbrella clause. ${ }^{72}$

Third, the Tribunal looked at the Claimant's reliance on the BIT's MFN clause. As an alternative argument, the Claimant submitted that it could use the MFN clause to import the umbrella clause from the Algeria-Switzerland BIT. This way the contractual breach could be

${ }^{66} \mathrm{Ibid}$. , para. 318.

${ }^{67}$ For similar 'formalistic' approaches (Cortesi (n 10), 118-19) see Salini Costruttori S.p.A. and Italstrade S.p.A. v. Kingdom of Morocco, ICSID Case No. ARB/00/4, Decision on Jurisdiction (16 July 2001). Arbitrators: Robert Briner (P), Ibrahim Fadlallah, and Bernardo Cremades; Consortium RFCC v. Kingdom of Morocco, ICSID Case No. ARB/00/6, Decision on Jurisdiction (16 July 2001), para. 34. Arbitrators: Robert Briner (P), Ibrahim Fadlallah, and Bernardo Cremades; Helnan International Hotels A/S v. The Arab Republic of Egypt, ICSID Case No. ARB/05/19, Decision of the Tribunal on Objection to Jurisdiction (17 October 2006), para. 91. Arbitrators: Yves Derains (P), Michael Lee, and Rudolf Dolzer.

${ }^{68}$ Consutel v Algeria (n 64), para. 321.

${ }^{69} \mathrm{Ibid}$., paras. 328-33.

${ }^{70}$ Ibid., para. 333.

${ }^{71} \mathrm{Ibid}$, para. 348. English translation from Italian: "Investments which have been the subject of a particular commitment by one of the Contracting States towards the nationals and legal persons of the other Contracting Party are governed, subject to the provisions of this Agreement, by the terms of this commitment insofar as the latter entails more favourable provisions."

${ }^{72}$ Ibid., paras. 350-52. 
elevated to a treaty breach. According to the Tribunal the MFN clause was unambiguous and allowed the Claimant to invoke more favourable clauses from another BIT of Algeria. ${ }^{73}$ It also rejected the Respondent's argument that the MFN clause could not be used to rely on another treaty's umbrella clause, as according to the Tribunal - citing again Arif v. Moldova - an umbrella clause is not procedural in nature, but substantive. Thus, the umbrella clause could be imported via the MFN clause. ${ }^{74}$

The Algeria-Switzerland BIT's umbrella clause states that "[e]ach of the Contracting Parties shall comply with all of its obligations with regard to investments made in the territory by investors of the other Contracting Party". ${ }^{75}$ The question thus arose as to whether this provision elevated a contractual breach to a treaty breach. The Tribunal, citing EDF $v$. Romania, held that the attribution of acts of public enterprises, such as AT, to the Respondent State did not replace AT as the contractual party with the consequence of making the State the debtor of AT's contractual obligations. In other words, because AT had a separate legal personality from the State, the State could not replace AT as a party to the contract. Thus, the imported umbrella clause did not cover AT's contractual obligations. ${ }^{76}$

The jurisdictional arguments attract further comments. First, it is questionable whether the attribution of the acts or omissions of state-owned enterprises (SOEs) to the Respondent State can be separated from the question of jurisdiction. According to some authors, attribution has both a procedural (jurisdiction) and a substantive component (liability). ${ }^{77}$ The procedural component is meant to ensure that the respondent is a State and not a private entity. Otherwise the dispute would not fall under the tribunal's jurisdiction. The substantive component (or attribution strictu sensu) establishes the liability of the State for the actions of such entity.

The Tribunal in Consutel relegated the issue of 'attribution' to the merits phase and for the purposes of the jurisdictional assessment it presumed that the SOE's actions and omissions were attributable to the State. However, attribution concerns mainly the link between the enterprise and the State, and not the legality of the enterprise's actions. ${ }^{78}$ It is therefore primarily a question of jurisdiction ratione personae. ${ }^{79}$ In other words, in the

\footnotetext{
${ }^{73} \mathrm{Ibid}$, paras. 354-56.

${ }^{74} \mathrm{Ibid}$., paras. 357-59.

${ }^{75}$ Ibid., para. 360.

${ }^{76} \mathrm{Ibid}$., paras. 363-67.

${ }^{77}$ Michael Feit, "Responsibility of the State under International Law for the Breach of Contract Committed by a State-Owned Entity", 28 Berkeley Journal of International Law (2010), 142, 144; Emilio Agustín Maffezini v. The Kingdom of Spain, ICSID Case No. ARB/97/7, Decision of the Tribunal on the Objections to Jurisdiction (25 January 2000), para. 75. Arbitrators: Francisco Orrego Vicuña (P), Thomas Buergenthal, and Maurice Wolf.

${ }^{78}$ Cortesi (n 10), p. 114.

${ }^{79}$ Ibid., p. 115.
} 
jurisdictional phase a tribunal should answer two important questions ratione personae that concern both disputing parties. First, is the Claimant an 'investor' that has made an 'investment' as defined by the underlying treaty? Second, do the challenged measures belong to the Respondent or another entity? ${ }^{80}$ If one of the questions is not satisfied the jurisdictional analysis comes to an end. Thus, in the present case the question of whether the actions and omissions $^{81}$ of AT were attributable to the Respondent (lato sensu) should have been answered first. In case of a negative answer, there would have been no need to analyse all the other intricate jurisdictional issues. ${ }^{82}$

Second, the Tribunal confirmed the existing case law that only those contractual breaches by a State or another entity - whose actions and omissions are attributable to the State - will amount to a breach of the treaty which have occurred during the exercise of sovereign, public powers. A mere contractual breach does not amount to a treaty breach. ${ }^{83}$

Third, the Tribunal - like the one in Arif v. Moldova - also differentiated between an umbrella clause and a so called 'preservation of rights clause', which according to the Arif Tribunal:

"simply says that in applying or enforcing the existing protections offered by the BIT, attention should be paid to any more favourable provisions contained in domestic law or specific agreements. [The clause] therefore confirms that the investor may benefit from more favourable treatment, but does not add a new, specific or distinct, treaty obligation to respect commitments made." $" 84$

Fourth, the Tribunal seems to side with those tribunals (e.g. Salini v. Jordan) ${ }^{85}$ that reject the application of the MFN clause to procedural matters. In other words, investors should not be allowed to use the MFN clause to import more favourable dispute settlement provisions from another treaty of the Respondent. However, the Tribunal still allowed for the importation of

${ }^{80}$ For a similar approach, see Toto Costruzioni Generali S.p.A. v. The Republic of Lebanon, ICSID Case No. $\mathrm{ARB} / 07 / 12$, Decision on jurisdiction (11 September 2009), para. 43. Arbitrators: Hans van Houtte (P), Alberto Feliciani, and Fadi Moghaizel.

${ }^{81}$ These should only be attributed to the State if they amount to a breach of an international obligation. See Feit (n 77) p. 155.

${ }^{82}$ For e.g. in Limited Liability Company Amto v. Ukraine, SCC Case No. 080/2005, Final Award (26 March 2008), para. 110. Arbitrators: Bernardo Cremades (P), Per Runeland, and Christer Söderlund. The Tribunal first looked at whether the SOE's contractual obligations were attributable to the State. Because they were not, there was no need to look at whether the breach of contract amounted to a breach of the umbrella clause.

${ }^{83}$ See Mr. Kristian Almås and Mr. Geir Almås v. The Republic of Poland, PCA Case No 2015-13, Award (27 June 2016). Arbitrators: James R. Crawford (P), Ola Mestad, August Reinisch.

${ }^{84}$ Mr. Franck Charles Arif v. Republic of Moldova, ICSID Case No. ARB/11/23, Award (8 April 2013), paras. 388-89. Arbitrators: Bernardo Cremades (P), Bernard Hanotiau, and Rolf Knieper.

${ }^{85}$ Salini Costruttori S.p.A. and Italstrade S.p.A. v. The Hashemite Kingdom of Jordan, ICSID Case No. ARB/02/13, Decision on Jurisdiction (9 November 2004), paras. 118-119. Arbitrators: Gilbert Guillaume (P), Bernardo Cremades, and Eric Schwartz. 
the umbrella clause from another BIT, by arguing that an umbrella clause is a substantive and not a procedural provision.

Fifth, even if an investor can use the MFN clause to import an umbrella clause from another BIT, such a clause does not seem to be effective in the case of SOEs, as the umbrella clause speaks of the State's commitments. Thus, the State cannot replace the SOE as a party to the underlying contract. Per a contrario, one could argue that if the other party to the contract is the State and not an SOE, then the umbrella clause is applicable.

As we can notice, even if the Tribunal wanted to relegate to the merits phase the question of attribution of the SOE's conduct, the issue kept resurfacing. It resurfaced in the question of whether the contractual breach amounted to a treaty breach (the lack of sovereign powers being exercised; contrast this to Article 5 ARSIWA on exercise of 'governmental authority'). It also resurfaced in the question of whether the umbrella clause covers contractual breaches of an SOE.

Thus, one may question whether the 'presumption of attribution' in the jurisdictional stage, adopted by the Tribunal in Consutel, serves the purpose of procedural economy. In the alternative, tribunals may address attribution in the jurisdictional phase early on, such as in Toto v. Lebanon. An even more flexible option, spearheaded by the Tribunal in Maffezini v. Spain, preserves the separation between jurisdiction and merits. In such a case, in the jurisdictional phase the tribunal would only require prima facie evidence of attribution from the claimant. A full analysis of the question of attribution would occur later in the merits stage, if still relevant.

\subsection{Insufficient evidence that the BIT entered into force}

The ICSID Additional Facility (AF) case of Besserglik v. Mozambique ${ }^{86}$ brings a smile to one's face. The case was initiated by South African investors against Mozambique under the Mozambique-South Africa BIT (1997) which, as it turned out, had never entered into force.

The Claimants, who had a joint venture with a Mozambique firm, alleged that the Respondent had unlawfully and fraudulently appropriated their fishing vessels and certain shares in the joint venture. Even though the claim was brought in 2014 and the Tribunal was constituted in 2015, it took the Respondent over two years two file its Motion to Dismiss. In its new jurisdictional objection, the Respondent argued that the BIT in fact had not entered into force. Under Article 12(1) of the BIT, the contracting parties had to "notify each other

${ }^{86}$ Oded Besserglik v. Republic of Mozambique, ICSID Case No. ARB(AF)/14/2, Award (28 Oct 2019). Arbitrators: Makhdoom Ali Khan (P), Yves Fortier, and Claus von Wobeser. 
promptly when their respective constitutional requirements for entry into force" of the Agreement had been fulfilled. Furthermore, the BIT was to enter into force "on the day following the day of receipt of the last notification." According to the Respondent neither South Africa nor Mozambique had notified each other of the ratification process. Thus, the agreement had never entered into force. The Respondent attached Diplomatic Notes from both countries affirming this and it furthermore argued that the UN Office of Legal Affairs had no records of the agreement having entered into force.

Obviously frustrated with this late and crucial objection to its jurisdiction, the Tribunal looked at whether Article 45(2) of the ICSID AF Arbitration Rules (similar to Rule 41(1) of the ICSID Arbitration Rules) allowed such a late submission. Article 45(2) provides that:

"(2) Any objection that the dispute is not within the competence of the Tribunal shall be filed with the Secretary-General as soon as possible after the constitution of the Tribunal and in any event no later than the expiration of the time limit fixed for the filing of the countermemorial or, if the objection relates to an ancillary claim, for the filing of the rejoinder-unless the facts on which the objection is based are unknown to the party at that time" [highlighted].

The Tribunal concluded that the Respondent did not file its objections "as soon as possible ${ }^{87}$ and it could not claim that it was unknown to it that the treaty had not entered into force. The Tribunal admitted that the conduct of the Respondent was in violation of Article 45(2) of the AFR Arbitration Rules which would "ordinarily have the consequence of the objection [...] being dismissed". ${ }^{88}$ Nevertheless, due to the Kompetenz-Kompetenz principle the Tribunal held that "it has an independent and continuing obligation, under Article 45(3) of the Arbitration Rules to «on its own initiative consider, at any stage of the proceeding, whether the dispute before it is within its competence»." 89

The Tribunal noted that there is no uniform practice on late jurisdictional objections. Furthermore, Article 45(2) of the AFR Arbitration Rules "cannot and does not negate the mandate of Article 41 of the [ICSID] Convention which requires a Tribunal to determine every objection to jurisdiction." 90 Because the objection referred to the non-entry into force of the BIT, it had to be considered as it affected the very consent of the Respondent to arbitration. ${ }^{91}$ According to the Tribunal "once an objection of such a fundamental nature has been brought to its attention the Tribunal cannot decline to consider it sua sponte". ${ }^{92}$

\footnotetext{
${ }^{87}$ Besserglik, paras. 265-282.

${ }^{88}$ Ibid., para. 307.

${ }^{89}$ Ibid.

${ }^{90}$ Ibid., paras. 311-12.

${ }^{91}$ Ibid., para. 315.

${ }^{92}$ Ibid., para. 317.
} 
The Tribunal thus had to analyse whether the formal requirements of Article 12(1) of the BIT on its entry into force had been met. Even though the Respondent acknowledged that the treaty was in fact ratified in accordance with its domestic procedures, the Claimant could not prove that the notifications were exchanged between the two contracting parties. Thus, the Tribunal concluded that the BIT had not entered into force and it declined its jurisdiction.

This case raises important questions concerning late jurisdictional objections. As the Tribunal rightly noted, there is no uniform approach. For example, the Tribunal in the recent case of PV Investors v. Spain, ${ }^{93}$ unlike the Tribunal in Besserglik, took a very strict view of the UNCITRAL Arbitration Rules and the Swiss Private International Law Act on late jurisdictional objections. It declined to open a new jurisdictional phase following Spain's late submissions concerning the CJEU's Achmea judgment.

Therefore, it seems that the underlying arbitration rules and their exact wording matter to the tribunals when deciding on whether to allow late jurisdictional objections. Furthermore, the Besserglik case involved a very serious objection to the Tribunal's jurisdiction. In intra-EU cases the parties do not deny the entry into force of the BITs. Instead, the objections concern the alleged tacit termination of these agreements or their incompatibility with the superseding EU Treaties (supra Sec 3.1), which leave tribunals a lot of interpretative discretion. In comparison, in Besserglik the Tribunal had little discretion to argue that the very agreement on which the Respondent's consent rested and based on which the Tribunal's jurisdiction depended did not in fact 'exist' under international law. This suggests that tribunals faced with late jurisdictional objections, which concern the very existence of the investment agreement under international law, will have reduced/no discretion to uphold their jurisdiction. Deciding otherwise would lead to an absurd outcome, even if the objection was submitted late.

\section{Tribunal orders to domestic authorities}

The interaction between arbitral tribunals and host State authorities has also witnessed new developments in the form of requests for interim measures. The requests often concern the disclosure or suspension of local criminal proceedings, as well as other measures aimed at the preservation of the integrity of the arbitral proceedings. This section focuses on claimant requests concerning criminal investigations in the host State.

\footnotetext{
${ }^{93}$ The PV Investors v. Spain, PCA Case No. 2012-14, Final Award of 28 Feb 2020, paras. 542-44.
} 
In the PCA case of Manolium v. Belarus the Tribunal was faced with the alleged intimidation of witnesses and the risk of the host State initiating criminal proceedings. ${ }^{94}$ The investor, a Russian company, brought a claim against Belarus under the Treaty on the Eurasian Economic Union (EEU, 2014). The Treaty establishes a single market within a customs union of five post-Soviet states: Armenia, Belarus, Kazakhstan, Kyrgyzstan, and Russia. Protocol No. 16 to the Treaty contains provisions on investment protection, which apply to all investments made by the nationals of the Contracting Parties from 1991 to the present. $^{95}$

To our knowledge, this is the first investment claim under the EEU Treaty, and it fell under the application of the UNCITRAL Rules on Transparency. ${ }^{96}$ Another peculiarity concerns the language of the proceedings. Russian, together with Belarusian, remain the two official languages of Belarus. ${ }^{97}$ Furthermore, the EEU Treaty was written in three equally authentic languages, Belarusian, Kazakh and Russian, the Russian version being preferred in cases of conflict. ${ }^{98}$ Considering the need for procedural economy, one would have expected the dispute to be conducted in Russian. However, the disputing parties agreed to conduct the arbitration in English, bringing additional translation-related hurdles. ${ }^{99}$ It seems likely that the explanation lies in the parties' desire to submit the dispute to an international forum of recognized expertise. ${ }^{100}$

The redacted version of the Decision on the Claimant's Interim Measures Request ${ }^{101}$ continues the growing line of cases in which investors resort to arbitral tribunals to prevent or postpone criminal proceedings brought against them in the host State. According to the agreed version of the facts, the Tax Authority of Belarus conducted a tax audit on the Claimant's subsidiary in the country. ${ }^{102}$ The audit found a significant tax debt and suggested that the persons allegedly responsible for it - the directors of the Claimant and its subsidiary - be investigated. ${ }^{103}$ The investigation was only of a preliminary nature and was aimed to

${ }^{94}$ OOO Manolium Processing v. The Republic of Belarus, PCA Case No 2018-06. Arbitrators: Juan FernándezArmesto (P), Stanimir Alexandrov, and Brigitte Stern.

${ }^{95}$ Treaty on the Eurasian Economic Union 2014, Protocol on Trade in Services, Incorporation, Activities and Investments (Annex XVI to the Treaty), Section 65.

${ }^{96}$ UNCITRAL Rules on Transparency in Treaty-Based Investor-State Arbitration (2013), Art. 1. The Rules apply to "Arbitration Rules pursuant to a treaty providing for the protection of investments or investors ("treaty") concluded on or after 5 April 2014 unless the Parties to the treaty have agreed otherwise".

${ }^{97}$ See 'General Information' (Belarus Facts, Ministry of Foreign Affairs of the Republic of Belarus, 2020) <http://belarusfacts.by/en/belarus/about/> accessed 5 April 2020.

98 TEEU (2014) final provisions.

${ }^{99}$ Manolium v. Belarus (n 94) Procedural Order No 1 (17 May 2018), para. 65-66.

${ }^{100}$ Ibid., para. 45.

101 Manolium v. Belarus (n 94), Decision on Claimant's Interim Measures Request (7 December 2018).

102 Ibid., para. 19.

${ }^{103}$ Ibid., para. 20. 
gather evidence for the potential institution of criminal proceedings. ${ }^{104}$ However, the investigation coincided with the bankruptcy proceedings initiated against another company of the Claimant. In these proceedings, the Belarusian Court directed the bankruptcy administrator to investigate the allegations of deliberate insolvency by the Company's management. As a result, both domestic proceedings concerned the alleged criminal misconduct of the same natural person, a key witness for the Claimant's case.

The Claimant requested the interim relief under Article 26 of the UNCITRAL Arbitration Rules (2013), alleging that the State's actions threatened the procedural integrity of the proceedings, the non-aggravation of the dispute, and the procedural equality of the parties. In particular, the Claimant submitted that the evidence obtained in the criminal proceedings might give the Respondent an unfair advantage during the arbitration. As a result, the Claimant requested the Tribunal to order Belarus to (1) abstain from initiating or suspend the ongoing criminal proceedings; (2) refrain from contacting the employees and witnesses of the Claimant, without its prior authorization and the Tribunal's permission; ${ }^{105}$ (3) refrain from any other measures posing risks to the integrity of the proceedings. ${ }^{106}$

The Respondent refuted the allegations as unsubstantiated, failing to satisfy the burden of proof. It submitted that the measures would interfere in the normal processes of justice in the State. ${ }^{107}$ Furthermore, there were no ongoing criminal investigations against the persons affiliated with the Claimant. ${ }^{108}$

The Tribunal agreed with the Respondent. It qualified the measures as 'moot or unnecessary' and rejected the request in its entirety. ${ }^{109}$ Regarding the criminal proceedings, it first reiterated the Respondent's argument that no such proceedings had taken place. Instead, Belarus was exercising its sovereign right to investigate tax evasion. The Tribunal also refused to order the Respondent to abstain from initiating criminal proceedings. According to the findings, the Claimant had not shown an urgency of such extraordinary measures. ${ }^{110}$ Nevertheless, the Tribunal retained the possibility of raising the issue again should the situation escalate and threaten the arbitral proceedings. ${ }^{111}$ Furthermore, the Claimant failed to add concrete evidence that the State intimidated its witnesses. ${ }^{112}$ Even

\footnotetext{
104 Ibid., para. 21.

105 The Claimant also alleged that the State coerced its own witnesses. The Tribunal rejected the allegations as falling short of the burden of proof.

106 Manolium v Belarus (Interim measures) (n 101) para. 107.

107 Ibid., para. 99.

108 Ibid., para. 100.

109 Ibid., para. 110.

110 Ibid., paras. 131-132.

111 Ibid., para. 133.

112 Ibid., para. 121.
} 
their own accounts contradicted the allegations of pressure from the State. Lastly, the Tribunal reminded the parties that the duty to prevent the aggravation of the dispute remained the common duty of both parties, which made any special measure against the Respondent redundant. ${ }^{113}$

The Tribunal then listed four general duties in arbitral proceedings, which both parties should respect "at all times." 114 The duties are especially important in investment proceedings due to the disparity of power between a private party and a sovereign State. ${ }^{115}$ The reference seems to imply that there is a higher expectation that the State comply with them.

According to the first duty, the parties are under an obligation not to aggravate the dispute. ${ }^{116}$ The Tribunal recalled that the duty was recognized by the PCIJ in 1939 and in subsequent arbitral decisions. ${ }^{117}$ The second duty requires the parties "not to obtain evidence improperly", which stems from the principles of good faith and equality of arms. ${ }^{118}$ As for the third duty, the duty "not to unduly influence the witnesses", the tribunal suggested that it "could be regarded" as a general principle of law, in accordance with Article 38(1)(c) of the ICJ Statute. ${ }^{119}$ However, the Tribunal did not elaborate on the status of the duty as a "general principle." Instead, it connected it with the right to be heard and more general duties to arbitrate in good faith and maintain the procedural integrity of the proceedings. ${ }^{120}$ Lastly, the Tribunal again referred to these general principles to substantiate a duty "not to exert pressure on the claimant or its representatives." 121 The fourth duty was exclusively directed to the State's attention.

The Tribunal rejected all the Claimant's requests for provisional measures. It further invited the Respondent to refrain from contacting the Claimant's employees and witnesses

\footnotetext{
113 Ibid., paras. 150-152.

114 Ibid., para. 154.

115 Ibid., paras. 155-156.

116 Ibid., paras. 157-158. Vicuña, B. Stern. paras. 62-64.

118 Manolium v Belarus (Interim measures) (n 101) paras. 159-162.

119 Ibid., para.163.

120 Ibid., paras. 164-167.

121 Ibid., paras. 168-170.
}

117 The Tribunal referred, in particular, to Electricity Company of Sofia and Bulgaria (Belgium v. Bulgaria), PCIJ series A/B, No 79, Order (5 December 1939) para. 199; City Oriente Limited v. Republic of Ecuador and Empresa Estatal Petróleos del Ecuador (Petroecuador), ICSID Case No ARB/06/21, Decision on Provisional Measures (19 November 2007). Arbitrators: Fernández-Armesto, Grigera Naón, and J. Chr Thomas. para. 57; Quiborax SA, Non Metallic Minerals SA and Allan Fosk Kaplún v. Plurinational State of Bolivia, ICSID Case No ARB/06/2, Decision on Provisional Measures (26 February 2010). Arbitrators: G. Kaufmann-Kohler, M. Lalonde, B. Stern. paras. 133-135; Burlington Resources Inc v. Republic of Ecuador, ICSID Case No ARB/08/5, Procedural Order No 1 (29 June 2009). Arbitrators: G. Kaufmann-Kohler, O. 
in the absence of their lawyers, and to refrain from discussions of their witness testimonies. ${ }^{122}$ The Tribunal concluded the order with a general recommendation for the parties to abstain from aggravating the dispute or violating the integrity of the proceedings. ${ }^{123}$

It is possible to separate the fact-related assessment of the Tribunal from the more abstract legal reasoning. Looking at the facts, it appears that the Claimant failed to establish the grounds for its requests. Any deeper investigation into the facts would turn incomplete due to parts of the decision being redacted for reasons of confidentiality. However, it is praiseworthy that the Tribunal made a brief summary - a reminder - of the parties' duties to preserve the integrity of the proceedings. In doing so, the Tribunal grounded the duties in the applicable arbitral rules and jurisprudence, presenting them as duties of general application. The four-part classification better articulates the abstract goals of "arbitrating in good faith", "not aggravating the dispute", and "preserving the integrity of arbitral proceedings."

In contrast, the Tribunal in Grace v. Mexico took a more favourable approach to granting provisional measures. ${ }^{124}$ The claim concerned the lease of oil drilling platforms owned by the Claimants to a Mexican state-owned company. According to the Statement of Claim, the state-owned company had unilaterally amended and later terminated the lease agreements without due compensation. ${ }^{125}$ The Claimants considered that these actions resulted in a breach of the FET, FPS and non-expropriation standards of NAFTA.

The Claimants then filed an application for interim measures, which was followed by an exchange of written arguments and a hearing by telephone. In the pleadings, the Claimants alleged that the State had launched multiple criminal investigations against them, their witnesses and lawyers. ${ }^{126}$ In addition, the Respondent obtained Interpol Red Notices to arrest and deliver two Claimants and three witnesses who were not residing in Mexico. ${ }^{127}$ In their prayer for relief, the Claimants requested the Tribunal to order the Respondent to refrain from arresting them or their witnesses, confirm the existence of criminal investigations against the Claimants' legal counsel and, in case of a positive answer, to suspend such proceedings. ${ }^{128}$ Lastly, the Claimants requested any other measures which the Tribunal might find appropriate to preserve their rights. ${ }^{129}$ In turn, the Respondent rebutted all allegations,

122 Ibid., para. 175 .

${ }^{123}$ Ibid., para. 176.

${ }^{124}$ Alicia Grace and others v. United Mexican States, ICSID Case No UNCT/18/4. Arbitrators: Diego P. Fernández Arroyo (P), Andrés Jana Linetzky and Gabriel Bottini.

${ }^{125}$ Ibid., Notice of Arbitration (19 June 2018) para. 4.

${ }^{126} \mathrm{Ibid}$, Procedural Order No 6 (Decision on the Claimant's Application for Interim Measures (19 December 2019) para. 20.

${ }^{127}$ Ibid., para. 21.

${ }^{128}$ Ibid., para. 36.

${ }^{129}$ Ibid. 
suggesting that the Claimants had failed to establish the necessity, urgency, and proportionality of the requested measures. ${ }^{130}$

The Tribunal reiterated that its mandate demanded the preservation of the integrity of the proceedings and protection against the aggravation of the dispute. It further proclaimed the "undisputed sovereign right of a State to pursue a criminal investigation within its territory". ${ }^{131}$ As for the Claimants' request, the Tribunal noted that the existence of any ongoing proceedings needed to be confirmed before deciding on their suspension. ${ }^{132}$

The Tribunal then looked at the measures requested by the Claimants. In order to be granted, the measures had to satisfy a threefold test. First, there must be a risk of damage (or "irreparable harm") if the interim measures are not adopted. Second, the claim should likely succeed on the merits. Third, the Tribunal has to evaluate the need, efficiency and proportionality of the requested measure. ${ }^{133}$ Notably, the test did not follow from the applicable provisions of NAFTA or the UNCITRAL Arbitration Rules, neither did it follow from the divergent submissions of the parties. ${ }^{134}$ The Tribunal constructed the test in its own fashion, while following the criteria "generally admitted" by other legal authorities. ${ }^{135}$

Rather surprisingly, the Tribunal then decided not to follow the criteria. Instead, it presented a more holistic overview of each of the measures, touching only upon the potential harm and their overall appropriateness. Regarding the first measure, the Tribunal indicated that none of the Claimants or their witnesses had been arrested to date. ${ }^{136}$ They also enjoyed the right to legal defence in their dealings with the Mexican authorities. ${ }^{137}$ In turn, the issue of Interpol Arrest Warrants was aimed at securing the criminal investigation of persons, residing outside of Mexico, and therefore served an appropriate purpose. ${ }^{138}$ The Tribunal concluded with a general non-aggravation request to the Respondent. ${ }^{139}$

However, the second measure, regarding the alleged criminal investigation of the Claimants' law firm, raised bigger concerns. The Tribunal indicated that the deprivation of the fundamental right of access to justice would be "extremely serious." 140 The existence of

\footnotetext{
130 Ibid., para. 40.

131 Ibid., para. 56.

132 Ibid., para. 59.

133 Ibid., para. 62.

134 Ibid., para. 61, 63.

135 Ibid., para. 63; referring, 'among others,' to 'Provisional Measures' (Institut de Droit International 2017)

Final resolution 3 Res s 2 <https://www.idi-iil.org/app/uploads/2017/08/3-RES-FINAL-EN-COR.pdf> accessed 5 April 2020.

136 Grace v. Mexico (PO 6) (n 129) para. 66.

137 Ibid., para. 67.

138 Ibid., para. 68.

139 Ibid., para. 69.

140 Ibid., para. 70.
} 
such investigations was not confirmed by the Respondent in its written submissions. During the oral hearings, the counsel for the Respondent submitted that no such proceedings had taken place. ${ }^{141}$ Left unsatisfied with this answer, the Tribunal requested the Respondent to provide "a concrete and formal answer" about the existence of any criminal investigations in relation to the Claimants' lawyers and the law firm. ${ }^{142}$

Several issues need consideration. First, the Tribunal distinguished between the measures requested for the Claimants and those for their lawyers. Whilst the potential criminal investigation of the former (including via Interpol Red Notices) did not raise significant concerns, the investigation of the lawyers required the adoption of specific interim measures. The Tribunal justified the increased attention by the risk of infringing the Claimants' fundamental right of access to justice.

Second, one can also draw parallels with the previously discussed Manolium v. Belarus. Both tribunals found the evidence presented in support of interim measures falling short of the required standard for granting them. In both cases, the Tribunals concluded their assessments with non-aggravation requests to the parties, calling for the preservation of the status quo. While it may seem that the Tribunal in Grace v. Mexico was more proactive in ordering Mexico to disclose any ongoing criminal proceedings, the decision does not go beyond that. Thus, both procedural orders conclude on the possibility of adopting further measures should the situation escalate.

\section{Conditional or Alternative Remedies}

Another issue we investigated are conditional or alternative remedies. The debate on whether tribunals can order specific performance is not new. ${ }^{143}$ Most tribunals will order the losing State to compensate the foreign investor for breaching the treaty standards and on some occasions they will order the restitution of the investor's property. ${ }^{144}$

The 2016 case of Arif v. Moldova ${ }^{145}$ is a curious outlier as the final award provides for a conditional remedy; the amount of compensation was conditioned by the Claimant accepting or refusing the return of one of his investments. We shortly discuss this case since

\footnotetext{
141 Ibid., para. 74.

142 Ibid.

143 See Michelle Bradfield and JC Thomas, "Non-Pecuniary Remedies: A Missed Opportunity?", 30 ICSID Review (2015), 635; Puloma Mukherjee and Akansha Dubey, "Double Remedies: A Feasible Option?", 14 The Journal of World Investment \& Trade (2013), 381; Berk Demirkol, "Remedies in Investment Treaty Arbitration", 6 JIDS (2015) 403.

${ }^{144}$ Demirkol (n 143), 408-09.

${ }^{145}$ Mr. Franck Charles Arif v. Republic of Moldova, ICSID Case No. ARB/11/23, Award (8 April 2013). Arbitrators: Bernardo M. Cremades (P), Bernard Hanotiau, and Rolf Knieper.
} 
we will compare it to the recent Hydro Energy 1 v. Spain. ${ }^{146}$ The claim was brought under the France-Moldova BIT and it concerned a public tender organized by Moldova for the operation of duty-free stores on the Moldavian border and in Moldavian airports. The Tribunal, even though it found a breach of the BIT's FET clause, ordered conditional remedies. The Respondent had 60 days to make proposals to the Claimant on the restitution of the investment in the airport store. If the Claimant accepted the restitution the Respondent had to pay a smaller sum as damages. However, if the Claimant rejected it the Respondent was liable for a larger sum.

Notably, the solution adopted by the Tribunal resembles a contractual instrument of asymmetrical (conditional or potestative) clauses, where one contracting party reserves a bigger choice of options than the other. Arbitration scholars often discuss them in the context of the unilateral choice of the dispute settlement forum. ${ }^{147}$ Such clauses may, under certain conditions, be void both in common and civil law jurisdictions, if they contradict the principle of good faith. ${ }^{148}$ There is some support for their nullity under international law as well. ${ }^{149}$ However, the risk of domestic courts scrutinising the Tribunal's solution in Arif is removed by the ICSID Convention's prohibition of the domestic review of arbitral awards. ${ }^{150}$

A somewhat similar remedy was also given in Hydro Energy 1 v. Spain. The Claimants, a Luxembourgish and a Swedish company, initiated the arbitration under the Energy Charter Treaty (ECT). They argued that Spain's changes to its regulatory framework applicable to producers of hydropower energy breached several provisions of the ECT, among which the prohibition of expropriation and the FET standard. ${ }^{151}$ The Respondent challenged the jurisdiction of the Tribunal using the recurring intra-EU arguments and the CJEU's Achmea judgment, given that the case concerned the intra-EU application of the ECT. The Respondent also objected to the Tribunal's jurisdiction, citing the taxation carve-outs in Articles 21 and 10(7) of the ECT. However, for this column, the remedies ordered in the Decision on Jurisdiction, Liability and Direction on Quantum are of interest.

\footnotetext{
${ }^{146}$ Hydro Energy 1 S.A.R.L. and Hydroxana Sweden AB v. Spain, ICSID Case No. ARB/15/42, Decision on Jurisdiction, Liability and Directions on Quantum (9 March 2020). Arbitrators: Lord Collins of Mapesbury (P), Rolf Knieper, and Peter Rees. Knieper was a wing arbitrator in Arif v. Moldova as well.

${ }^{147}$ Deyan Draguiev, "Unilateral Jurisdiction Clauses: The Case for Invalidity, Severability or Enforceability", 31 Journal of International Arbitration (2014), 19; Bas van Zelst, "Unilateral Option Arbitration Clauses: An Unequivocal Choice for Arbitration under the ECHR?", 25 Maastricht Journal of European and Comparative Law (2018), 77.

${ }^{148}$ See Ulrike Babusiaux, "Introduction before Art 16:101", in N. Jansen and R. Zimmermann (eds.), Commentaries on European Contract Laws (2018), 1935.

${ }^{149}$ Certain Norwegian Loans (France v. Norway), ICJ Judgment of 6 July 1957, Separate opinion of Judge Sir Hersch Lauterpacht, paras. 49-50.

${ }^{150}$ Art. 53(1) ICSID Convention excludes all post-award remedies, except for those provided in the Convention, precluding domestic court control over the question of enforcement.

${ }^{151}$ Hydro Energy 1 v. Spain (n 146), paras. 5-6.
} 
After having held that the Spanish measures amounted to a breach of the "FET obligation of stability (or the legitimate expectation of stability)", ${ }^{152}$ the Tribunal looked at the issues of liability and compensation as - due to the type of the case - a close connection existed between them. ${ }^{153}$ The parties could not agree on the value of the post-tax reasonable rate of return concerning the Claimant's investment in the renewable energy sector. Given this uncertainty, and after a complex and technical analysis in which the Tribunal relied heavily on the methodology used in RREEF $v$. Spain, ${ }^{154}$ it came up with a unique decision and remedy. First, the Respondent "might (or would) be" in breach of Article 10(1) of the ECT (the FET standard) ${ }^{155}$ if the remuneration of each of the investors' investments "failed to accord with a reasonable post-tax rate of return" based on a specific calculation. ${ }^{156}$ Second, the Tribunal directed the parties to agree on the level of the reasonable post-tax rate of return and post-tax holdings and to report back to it within 60 days on whether they managed to reach an agreement. ${ }^{157}$

Some comments follow. First, the case is similar to Arif v. Moldova to the extent that both decisions include a certain conditionality. However, there is an important difference. In Arif the Tribunal found that the Respondent breached the BIT's FET clause, but conditioned the remedy and the overall amount of damages on whether the Claimant accepted the return of one of his investments. Thus, the remedies and the amount of damages were conditioned and not the finding of a violation of the BIT. Conversely, in Hydro Energy 1 the finding of a breach of the ECT was conditioned by the disputing parties' subsequent agreement and not the remedy or the amount of compensation per se.

Second, one wonders whether a decision that does not clearly state that the Respondent has breached the treaty, respects the principle of finality of awards under the ICSID Convention. One could argue that the Decision in Hydro Energy 1 is not a final award under Article 48 ICSID Convention, as the Tribunal did not decide in a definitive manner on all the issues before it (the breach of the FET standard). Thus, the principle of finality should not apply to this interlocutory decision. However, there is some academic support that within the ICSID system interlocutory decisions that resolve a dispute between the parties are final, but under certain conditions the tribunals may later reconsider them. ${ }^{158}$ Thus, the principle of

\footnotetext{
${ }^{152}$ Ibid., para. 682.

${ }^{153} \mathrm{Ibid}$, para. 685.

${ }^{154}$ RREEF Infrastructure (G.P.) Limited and RREEF Pan-European Infrastructure Two Lux S.à r.l. v. Kingdom of Spain, ICSID Case No. ARB/13/30.

${ }^{155}$ Even though previously in para. 682 the Tribunal held that Spain's measures amounted to a breach of the FET standard.

${ }^{156}$ Hydro Energy 1 v. Spain (n 146), para. 770 point 3.

${ }^{157} \mathrm{Ibid}$., para. 770 points 4-5.

${ }^{158}$ Lisa M. Bohmer, "Finality in ICSID Arbitration Revisited", 31 ICSID Review (2016), 246, 240.
} 
finality could apply to pre-award decisions unless the Tribunal decides to later reconsider them under certain conditions. Because in Hydro Energy 1 the Tribunal conditioned the finding of a breach of the FET standard on the parties' subsequent agreement, the Tribunal should be able to revisit the Decision in the final award.

\section{Domestic recognition, enforcement, and execution}

\subsection{State immunity from recognition/enforcement $v$. immunity from execution}

The Spanish renewable cases are well known and discussed in the literature. What caught our eyes was the recent domestic enforcement case brought before the Federal Court of Australia (FCA) ${ }^{159}$ by the investors in Eiser v. Spain. ${ }^{160}$ Judge Stewart J. delivered a wellreasoned judgment on the difference between State immunity from recognition/enforcement and immunity from execution.

The FCA granted leave to the applicants under the International Arbitration Act 1974 of Australia to enforce the ICSID award rendered against Spain. The Respondent argued that it was covered by Section 9 of Australia's Foreign States Immunities Act of 1986 (Immunities Act), which provides that a "foreign State is immune from the jurisdiction of the courts of Australia in a proceeding". However, Section 10 covers several exceptions from the immunity from jurisdiction rule, which include the situation when the foreign state submits to the local jurisdiction under an "agreement". The definition of "agreement" under Section 3(1) of the Immunities Act includes international treaties.

Therefore, the domestic court had to answer how the local Immunities Act interacted with the ICSID Convention and whether a foreign State was "immune from the recognition and enforcement of an arbitral award" made under the ICSID Convention. ${ }^{161}$ The FCA first looked at the Immunities Act. The Act differentiates between immunity from jurisdiction (Section 9) and immunity from execution (Section 30). The latter only applies in cases when the foreign State is not immune from jurisdiction. Section 30 also protects a foreign State's property from "[...] any process or order (whether interim or final) of the courts of Australia for the satisfaction or enforcement of a judgment, order or arbitration award [...]". Thus, it was crucial for the local court to decide whether the recognition and enforcement of ICSID awards fell under immunity from jurisdiction or immunity from execution.

\footnotetext{
${ }^{159}$ Eiser Infrastructure Ltd v. Kingdom of Spain [2020] FCA 157, NSD 601 and 602 of 2019.

${ }^{160}$ Eiser Infrastructure Limited and Energía Solar Luxembourg S.à r.l. v. Kingdom of Spain, ICSID Case No. $\mathrm{ARB} / 13 / 36$.

${ }^{161}$ Eiser v. Spain (FCA) (n 162), para. 1.
} 
The FCA embarked on a very detailed analysis of the ICSID Convention to decipher whether Articles 54 and 55 made a difference between recognition/enforcement and execution. The judge relied on Articles 31 and 32 of the VCLT, the preparatory works of the ICSID Convention, the writings of Aaron Broches, Christopher Schreuer, and several foreign court decisions. It held that:

"134. [...] on the proper construction of the Investment Convention [ICSID], Spain by becoming a Contracting State expressly submitted to the jurisdiction of the courts of other Contracting States in respect of the recognition and enforcement, but not execution, of any resulting award." [emphasis added]

In other words, the recognition and enforcement of the award fell under Section 9 of the Immunities Act (immunity from jurisdiction) and Spain waived this immunity under Section 10(1) by agreeing to the ICSID Convention. Thus, the FCA concluded that the claimants "were entitled to the recognition and enforcement of the awards" and "they have established that they are entitled to such leave and to judgments in their favour for payment of the pecuniary obligations of the awards". ${ }^{162}$ Nonetheless, the judgment and the Immunities Act (Section 30) clearly separate between immunity from jurisdiction and immunity from execution. The investors now have an Australian judgment recognizing the ICSID award. However, the actual freezing or sale of Spain's assets would be covered by immunity from execution under Section 30. This immunity can also be waived by "an agreement of the foreign State" (Art. 31(3) Immunities Act) which begs the question of whether Article 54(3) of the ICSID Convention would satisfy this requirement. ${ }^{163}$

Whilst on a first read the case seems to have brought some novelty to the recognition, enforcement, and execution of ICSID awards, the FCA judgment in fact follows the line of arguments made by Broches and several French cases cited in the judgment. The existence of two kinds of immunities requires a separate waiver of each of them. ${ }^{164}$ In the absence of the Spanish waiver of immunity from execution, the Claimant will need to identify and successfully seize the State's property not covered by sovereign immunity. The question belongs to domestic law, applied by Australian courts in a reportedly state-friendly fashion. ${ }^{165}$

162 Ibid., paras. 209-211.

163 Article 54(3) ICSID Convention "(3) Execution of the award shall be governed by the laws concerning the execution of judgments in force in the State in whose territories such execution is sought."

164 August Reinisch, "European Court Practice Concerning State Immunity from Enforcement Measures", 17 European Journal of International Law (2006), 803, 817.

165 Michael Douglas and Claudia Carr, "The Commercial Exceptions to Foreign State Immunity", 45 Federal Law Review (2006), 445 (concluding that the current application of the 'commercial exception' in Australia is inconsistent with the principle of restricted sovereign immunity); Michael Douglas, "Australia's First 
The existing examples of successful seizures of assets in other jurisdictions include mostly commercial property and assets of state-owned companies. ${ }^{166}$ In certain cases, such attempts of seizure may cause diplomatic tensions between the respondent State and the State where enforcement takes place. ${ }^{167}$ However, and as an alternative, the ICSID Convention authorizes the resort to diplomatic means in cases of non-payment. Under a rather 'exotic' procedure prescribed in Article 27 of the ICSID Convention, the home State of the investor may espouse its claim in order to exercise diplomatic protection or bring an international claim against the debtor State. ${ }^{168}$ Nevertheless, private enforcement against State property not covered by immunity involves some lesser sovereign discretion, and thus arguably remains a more feasible option than the eventual espousal of the claim by the home State.

In conclusion, whilst the investors can rejoice that they have obtained a local judgment recognizing and enforcing their ICSID award, whether or not it remains a "piece of paper" or it will result in the freezing of Spain's assets remains to be seen.

\subsection{A National Court's Reference to the CJEU Concerning the Application and Interpretation of Achmea}

In the Stockholm Chamber of Commerce (SCC) case of PL Holdings v. Poland ${ }^{169}$ a Luxembourg based company brought a case against Poland under the BLEU-Poland BIT. PL Holdings, who owned 99\% of two Polish banks, alleged that the Respondent had expropriated its assets. The Tribunal agreed with the Claimant. In a first award it held that Poland breached the BIT while in a second award it awarded damages to the investor.

Poland challenged both awards before the Svea Court of Appeal, arguing that they were not based on a valid arbitration agreement following the CJEU's Achmea ruling. The Court of Appeal rejected Poland's arguments and concluded that the awards were not invalid, and

Contested ICSID Enforcement" (Conflict of Laws, 29 February 2020)

<https://conflictoflaws.net/2020/australias-first-contested-icsid-enforcement/> accessed 5 April 2020.

${ }^{166}$ See Andrea K. Bjorklund, "State Immunity and the Enforcement of Investor-State Arbitral Awards" in Ch. Binder and others (eds.), International Investment Law for the 21 st Century (2009), 314-316 (describing the Franz Sedelmayer enforcement saga against Russia); Dmitry Gololobov, "The Prospect of Enforcement of Hague Arbitration Awards against State-Controlled Companies in the United States and the United Kingdom", 3 Russian Law Journal (2015), 7.

167 "Press Release on Summoning the Ambassador of the Kingdom of Belgium to Russia" (Ministry of Foreign Affairs of Russia, 18 June 2015) <https://www.mid.ru/foreign_policy/news//asset_publisher/cKNonkJE02Bw/content/id/1458018> accessed 5 April 2020; The Moscow Times, "Russia Reacts to Reports of State Assets Seized in Europe Over Yukos Case" (The Moscow Times, 18 June 2015) $<$ https://www.themoscowtimes.com/2015/06/18/russia-reacts-to-reports-of-state-assets-seized-in-europeover-yukos-case-a47494> accessed 5 April 2020.

${ }_{168}$ Art 27(1) ICSID Convention; Bjorklund (n 166) 306-307.

${ }^{169}$ PL Holdings S.à.r.l. v. Republic of Poland, SCC Case No. V 2014/163. 
they were not contrary to Swedish ordre public. Only a minor part of the final award was set aside as the Tribunal made a late addition to one of the awards, exceeding its mandate. ${ }^{170}$

The Court of Appeal compared the ISA clause of the Netherlands-Slovakia BIT from the Achmea case with the similar clause of the BLEU-Poland BIT. It concluded that they were similar as both related to disputes brought by investors under investment treaties concluded between EU Member States. ${ }^{171}$ However, the present case differed form Achmea in two ways. First, in Achmea the EU law objection to jurisdiction was raised in the statement of defence while in PL Holdings Poland raised the objection later.

Second, the Court of Appeal focused on the part of the CJEU's Achmea judgment ${ }^{172}$ in which the latter differentiated between investment treaty arbitration and commercial arbitration. According to the CJEU, the former is derived "from a treaty by which Member States agree to remove [a dispute] from the jurisdiction of their own courts" while the latter "originate[s] in the freely expressed wishes of the parties". ${ }^{173}$ Somewhat surprisingly, the Court of Appeal read this part of the Achmea judgment as meaning that if an arbitration agreement is made following the joint expression of party autonomy - even if it is based on an intra-EU BIT that is incompatible with EU law - it does not violate EU law! Thus, "[t]he conclusion from the Achmea ruling is therefore that articles 267 and 344 TFEU would not as such preclude Poland and PL Holdings from entering into an arbitration agreement and participating in arbitral proceedings regarding an investment-related dispute." 174

The conclusions of the Svea Court are more than perplexing. According to the CJEU in Achmea, investment treaty arbitration is to be differentiated from commercial arbitration because in the case of the former, the arbitration - and thus the arbitration agreement as well - is derived from the sovereign will of two States that decide to remove certain disputes from their courts. The arbitration is not derived from the free will of two disputing commercial parties. One can of course debate the extent to which a State's standing offer to arbitrate via an investment treaty and its subsequent 'acceptance' by the investor is a 'free expression' of the intent to arbitrate. Nevertheless, the Achmea judgment is quite clear that the basis of that 'arbitration agreement' implies the exercise of a State's sovereign powers via the conclusion of a treaty. Conversely, commercial arbitration does not. We have seen that this separation between a State's sovereign and private capacity also matters for a State's contractual breaches that could only amount to a breach of the treaty if the State exercised governmental authority (see Section 3.2).

\footnotetext{
${ }^{170}$ Svea Court of Appeal, Poland v. PL Holdings, Case No. T 8538-17 T 12033-17, Ruling of 22 Feb 2019.

${ }^{171}$ Ibid., page 41.

${ }^{172}$ Ibid., page 41-43.

${ }^{173}$ CJEU Slovak Republic v Achmea BV, ECLI:EU:C:2018:158, para. 55.

${ }^{174}$ Svea Court of Appeal, page 43.
} 
It is no wonder then that Poland appealed, and the Swedish Supreme Court referred the following question to the CJEU:

"Does Articles 267 and 344 TFEU, as interpreted in Achmea, mean that an arbitration agreement is invalid if it has been concluded between a Member State and an investor - where an investment treaty contains an arbitration clause that is invalid because the treaty was concluded between two Member States - as a result of the Member State, when the investor called for arbitration, refraining from making any valid objections to the jurisdiction due to its own free will through passivity?" 175 [own translation]

The CJEU will probably conclude that Achmea precludes any type of 'agreement to arbitrate' based on an intra-EU investment treaty. How could the 'agreement to arbitrate', which rests on the host State's open offer to arbitrate under a BIT, remain valid under EU law if the ISA clause of the intra-EU BIT is incompatible with EU Law?

The somewhat artificial difference made by the Svea Court between the BIT's ISA clause and the 'arbitration agreement' might be due to how the Swedish Arbitration Act defines an 'arbitration agreement' as being concluded in writing, most often by way of an arbitration clause included in a contract' or 'by implicit conduct'. ${ }^{176}$ Regardless of how the lex arbitri defines the 'arbitration agreement', from Achmea it is evident (and the CJEU should confirm this clearly) that arbitration and thus 'arbitration agreements' based on ISA provisions found in intra-EU BITs will be precluded by EU law. Since EU law has primacy over national law, including the Swedish Arbitration Act, this should not be an issue.

${ }^{175}$ Supreme Court of Sweden, Poland v. PL Holdings, Case No. T 1569-19, para. 57.

${ }^{176}$ Svea Court of Appeal, page 37. 